\title{
Celebrating 100 volumes
}

\author{
Robert W. Howarth
}

Published online: 22 August 2010

(C) Springer Science+Business Media B.V. 2010

Wow, 100 volumes of Biogeochemistry! In celebration, Editor-in-Chief Kate Lajtha asked me to write a brief editorial, my chance for a little reminiscence. The journal was the brain child of Ad Plaizier, a Wageningen-trained soil scientist turned young publisher for Dr. W. Junk back in the early 1980s. Plaizier saw the open niche for Biogeochemistry, and worked aggressively to make the journal a reality. He recruited me to serve as first Editor-in-Chief, although at first I was openly skeptical of the need for a new journal. Ad knew, however, not only that there was room for a quality journal, but a need for a journal to better integrate the discipline of biogeochemistry. At the annual meeting of the Ecological Society of America that summer, John Stewart and other colleagues (participants in a special session on the role of sulfur in ecosystem processes) also worked to convince me of the need. When I returned home from that meeting, I was greeted by a letter of rejection for a manuscript I had submitted to Geochimica et Cosmochimica Acta. Although the paper was favorably reviewed, the editor wrote that my topic was "too biological" for their geochemical

R. W. Howarth $(\bowtie)$

Department of Ecology and Evolutionary Biology, Cornell University, Ithaca, NY, USA

e-mail: howarth@cornell.edu

R. W. Howarth

Marine Biological Lab, The Ecosystems Center,

Woods Hole, MA, USA journal. That convinced me to take on the challenge of starting Biogeochemistry.

Ad Plaizier and I jointly recruited a world class team of Associate Editors and editorial board members: John Aber, Gilles Billen, Bert Bolin, Tom Brock, Yehuda Cohen, Dave Des Marais, Steve Emerson, Robert Garrels, Jim Gosz, Hank de Haan, Charlie Hall, Rafael Herrera, Bob Hodson, Bo Barker Jorgensen, Don Kinsey, Cindy Lee, Fauzi Mantoura, Chris Martens, Jerry Melillo, Judy Meyer, Bill Patrick, Bill Reiners, Thomas Rosswall, John Rudd, Dave Schindler, Bill Schlesinger, Rene Schwarzenbach, John Stewart, Werner Stumm, Michael Swift, and Alex Zehnder. Their energy and enthusiastic support was critical to the journal in its early stages. Over the fall of 1983, I also recruited manuscripts for submission, including the papers from the special symposium on sulfur in ecosystem processes at ESA, which made up our first issue, published in January 1984.

Over time, the journal changed publishing houses, as Dr. W. Junk was bought out by Martinus Nijhoff, which in turn was purchased by Kluwer, which eventually merged with Springer. Ad Plaizier remained the publisher through much of this time, even as he was promoted to every higher positions in the publishing houses. Eventually, he turned over the publishing of Biogeochemistry to others. These individuals too have always been extremely supportive of the journal, for which I am deeply grateful.

By 2004 after 20 years as Editor-in-Chief, I realized it was time (past time?) to pass the job on. 
With the full support of the publishers at Springer, I was able to convince Kate Lajtha to become Editorin-Chief. She and I had by that time been sharing the job as co-Editors-in-Chief for several years, and Kate had demonstrated her energy, wisdom, and dedication. Biogeochemistry has continued to thrive under her leadership, and I have been pleased to keep some level of involvement as "Founding Editor."

Biogeochemistry has filled an important need for our discipline from the start 26 years ago. The journal continues to do well with an impact factor in recent years of $\sim 3$, placing it in the top $15 \%$ of all environmental science journals and the top $11 \%$ of all geoscience journals. Although other journals such as Global Biogeochemical Cycles have been started since 1984 and have also contributed greatly to the field of biogeochemisty, Biogeochemistry was the first journal in this field, a field that has grown ever increasingly central to a world faced by global climate disruption and other aspects of humanaccelerated environmental change.

In the preface to the first issue of volume 1 back in 1984, I wrote: "Biogeochemistry is a highly interdisciplinary and diverse field. Scientific papers in this field appear in over forty journals, and yet biogeochemistry is not the primary focus of any existing journals. We introduce Biogeochemistry in the belief that there is a need for a common outlet for the publication of scientific papers on biogeochemistry and in the hope that the journal will serve as an integrative force in this developing field." I am thrilled at the success of the journal in meeting this challenge, and honored to have been able to have played a part. 